\title{
Pengaruh Motivasi Belajar dan Penguasaan Kosakata terhadap Kemampuan Menulis Naratif Bahasa Inggris
}

\author{
Elis Solihat \\ Pendidikan Bahasa Inggris, STKIP Pancakarya Tangerang \\ elissolihat25@gmail.com
}

\begin{abstract}
Abstrak
Tujuan penelitian ini adalah untuk mengetahui pengaruh motivasi belajar dan penguasaan kosakata secara bersama-sama terhadap kemampuan menulis naratif bahasa Inggris pada siswa SMP Swasta di Kota Bogor. Metode penelitian yang digunakan adalah metode survei dengan jumlah sampel 90 siswa yang dipilih secara random pada tiga SMP Swasta di Kota Bogor. Penelitian ini menggunakan tiga instrumen yaitu motivasi belajar berbentuk angket, instrumen penguasaan kosakata dan kemampuan menulis naratif bahasa Inggris berbentuk tes tertulis. Teknik analisis data dalam penelitian ini adalah analisis korelasi dan regresi. Berdasarkan hasil penelitian menunjukan: (1) Terdapat pengaruh yang signifikan motivasi belajar dan penguasaan kosakata secara bersama-sama terhadap kemampuan menulis naratif bahasa Inggris siswa SMP Swasta di Kota Bogor. Hal ini dibuktikan dengan perolehan nilai Sig. $=0,000<0,05$ dan $F_{\mathrm{h}}=13,905$. (2) Terdapat pengaruh yang signifikan motivasi belajar terhadap kemampuan menulis naratif bahasa Inggris siswa SMP Swasta di Kota Bogor. Hal ini dibuktikan dengan perolehan nilai Sig. $=0,000<0,05$ dan $t_{\mathrm{h}}=3,764$. (3) Terdapat pengaruh yang signifikan penguasaan kosakata terhadap kemampuan menulis naratif bahasa Inggris siswa SMP Swasta di Kota Bogor. Hal ini dibuktikan dengan perolehan nilai Sig. $=0,011<0,05$ dan $t_{\mathrm{h}=2,600}$.
\end{abstract}

Kata kunci: menulis naratif bahasa Inggris, motivasi belajar, penguasaan kosakata.

Dikirim: 09 November 2020

Direvisi: 30 Desember 2020

Diterima: 02 Januari 2021

\section{Identitas Artikel:}

Solihat, E. (2021). Pengaruh Motivasi Belajar dan Penguasaan Kosakata terhadap Kemampuan Menulis Naratif Bahasa Inggris. Jurnal Ilmu Pendidikan (JIP) STKIP Kusuma Negara, 12(2), 119-131.

\section{PENDAHULUAN}

Sebagai bahasa internasional, bahasa Inggris memiliki pernanan penting untuk berkomunikasi antar warga bangsa. Hal ini sejalan dengan peranan bahasa Inggris sebagai bahasa yang sering digunakan untuk berkomunikasi dengan berbagai negara, baik sebagai bahasa pertama, kedua, maupun bahasa asing (Crystal, 2003). Di Indonesia, banyak sekolah yang menerapkan pembelajaran bahasa Inggris dimulai dari jenjang Taman Kanak-kanak dan juga jenjang Sekolah Dasar. Hal ini dimaksudkan agar siswa lebih mudah mempelajari bahasa Inggris yang wajib dipelajari di Sekolah Menengah Pertama (SMP). Pentingnya bahasa Inggris di Indonesia sebagai bahasa asing yang dipelajari di SMP, siswa diharapkan mampu menguasai empat keterampilan bahasa Inggris, yaitu menyimak (listening), berbicara (speaking), membaca (reading) dan menulis (writing). Dalam pembelajaran menulis (writing) di SMP, ada beberapa jenis teks yang harus dikuasai siswa, salah satunya naratif bahasa Inggris. Mengingat pentingnya kemampuan menulis teks naratif bahasa Inggris, maka sangat diharapkan siswa 
dapat memahami penulisan naratif bahasa Inggris secara menyeluruh agar hasil kemampuan siswa dalam menulis narartif bahasa Inggris maksimal.

Berdasarkan hasil observasi yang dilakukan peneliti dikalangan siswa SMP kelas VII terhadap proses pembelajaran menulis naratif bahasa Inggris, ternyata persentase siswa yang mendapatkan nilai di bawah Kriteria Ketuntasan Minimum (KKM) yaitu 70\%. Ada dua faktor yang menyebabkan rendahnya kemampuan menulis naratif bahasa Inggris, yaitu faktor internal atau faktor yang berasal dalam diri dan faktor eksternal atau faktor yang berasal dari luar. Faktor-faktor yang berasal dalam diri siswa meliputi kesehatan, rasa aman, kemamampuan intelektual, afektif misalnya mengenai tentang perasaan dan kepercayaan diri, motivasi atau keinginan untuk belajar, kematangan belajar, jenis kelamin, usia, latar belakang sosial, kebiasaan dalam belajar, daya ingat, dan kemampuan pengindraan (melihat, mendengar atau merasakan). Sedangkan faktor-faktor yang berasal dari luar siswa yaitu, faktor sosial dan faktor non-sosial. Faktor sosial yaitu lingkungan keluarga, lingkungan sekolah, dan lingkungan masyarakat. Faktor non-sosial diantaranya adalah sarana dan prasarana sekolah, waktu belajar, rumah dan alam (Siregar \& Nara, 2014).

Faktor-faktor di atas, yang paling banyak ditemukan dalam kemampuan menulis naratif bahasa Inggris adalah motivasi belajar dan penguasaan kosakata bahasa Inggris siswa. Hal ini terlihat dari hasil wawancara dengan guru SMP kelas VII menunjukkan bahwa siswa cenderung bermalas-malasan untuk belajar dan juga tidak mengerjakan tugas yang diberikan oleh guru. Siswa yang memiliki prestasi rendah tidak menjamin kemampuan siswa tersebut rendah, namun bisa disebabkan oleh dorongan atau motivasi yang tidak didapatkan oleh siswa tersebut (Sanjaya, 2008). Motivasi belajar menjadi hal utama dalam belajar, karena dapat memberikan pengaruh besar dalam membangkitkan kemauan untuk belajar. Motivasi belajar merupakan dorongan yang berasal dari dalam diri dan luar diri siswa yang sedang belajar untuk melakukan suatu usaha yang meliputi unsur-unsur adanya keinginan atau untuk berhasil, dorongan kebutuhan belajar, cita-cita dimasa mendatang, harapan, penghargaan dalam belajar serta lingkungan belajar yang nyaman (Uno, 2011).

Siswa yang tidak memiliki motivasi tidak akan melakukan usaha apapun agar mampu menulis naratif bahasa Inggris dengan baik. Permasalahan tersebut menyebabkan siswa mengalami kesulitan dalam menulis naratif bahasa Inggris, terutama memperkaya kosakata bahasa Inggris. Mereka sulit mencari ide dan mengembangkan tulisan naratif bahasa Inggris dengan baik. Penguasaan kosakata yang baik memudahkan siswa dalam mengembangkan tulisan yang baik dan bermakna. Dalam memiliki kualitas tulisan yang baik, penggunaan ejaan, kosakata dan penyusunan kalimat sangat penting dimiliki karena siswa yang memiliki penguasaan kosakata yang tinggi akan mudah menuangkan ide dalam tulisannya (Nurjamal, 2010). Semakin banyak kosakata yang dimiliki seseorang, maka akan besar pula kemungkinanan seseorang terampil dalam berbahasa.

Kuantitas dan kualitas kosakata menentukan keberhasilan siswa dalam keterampilan berbahasa. Kuantitas dan kualitas kosakata dapat menentukan kualitas keterampilan berbahasa seseorang (Tarigan, 2015). Siswa yang memiliki motivasi belajar dan memiliki penguasaan kosakata akan mampu mengekspresikan gagasan dan mampu memilih kata-kata yang tepat dalam menulis naratif bahasa Inggris. Memiliki motivasi belajar berati siswa mampu melakukan suatu upaya dalam 
meningkatkan kemampuan menulisnya dengan baik, baik struktur kalimat, pemilihan kata yang tepat, generic structure, makna sebuah kata atau kalimat dan elemen-elemen yang terdapat dalam penulisan naratif. Dalam meningkatkan kemampuan siswa menulis naratif bahasa Inggris, motivasi belajar yang tinggi dan penguasaan kosakata yang banyak membantu siswa dalam menuangkan ide dan memilih penggunaan kata dan kalimat yang tepat dalam menulis naratif bahasa Inggris.

Oleh karena itu, motivasi belajar dan penguasaan kosakata sangat penting dimiliki siswa dalam menulis naratif bahasa Inggris. Keduanya memiliki hubungan yang sangat erat dalam menentukan keberhasilan menulis naratif bahasa Inggris siswa. Motivasi belajar merupakan hal yang penting dalam kegiatan belajar, karena tanpa motivasi seseorang tidak akan menambah ilmu pengetahuannya, baik secara lisan maupun tulisan. Mereka tidak akan berupaya untuk meningkatkan kemampuannya dalam belajar. Begitu halnya dengan penguasaan kosakata, siswa yang tidak memperkaya kosakata akan mengalami kesulitan dalam menulis naratif bahasa Inggris, karena menulis naratif bahasa Inggris merupakan kegiatan yang harus dilatih secara berkesinambungan dan didukung oleh motivasi yang tinggi pada siswa. Tujuan dari penelitian ini adalah sebagai berikut: (1) untuk mengetahui pengaruh motivasi belajar dan penguasaan kosakata secara bersama-sama terhadap kemampuan menulis naratif Bahasa Inggris; (2) mengetahui pengaruh motivasi belajar terhadap kemampuan menulis naratif bahasa Inggris; (3) mengetahui pengaruh penguasaan kosakata terjadap kemampuan menulis naratif bahasa Inggris pada siswa SMP Swasta di Kota Bogor.

\section{METODE PENELITIAN}

Penelitian ini dilaksanakan di tiga SMP Swasta kota Bogor. Ketiga sekolah tersebut yaitu SMP Yayasan Zaelani Mansyur 2 Bogor, SMP Rimba Teruna Bogor dan SMP Infokom Bogor. Adapun siswa yang akan diteliti di ketiga sekolah tersebut adalah siswa kelas VIII. Desain penelitian yang digunakan dalam penelitian ini yaitu metode survei. Metode ini merupakan penelitian untuk penelitian kuantitatif, yaitu menggunakan pertanyaan yang sama pada setiap individu yang diteliti. Setelah itu, peneliti mencatat, mengolah dan menganalisis semua jawaban dari individu. Kerlinger (2003) menyatakan bahwa metode survei merupakan metode yang mampu membuat tafsiran yang akurat tentang karakteristik-karakteristik keseluruhan populasi.

Ada tiga varibel yang akan diteliti dalam penelitian ini, yaitu dua variabel bebas (independent variable) dan satu variabel terikat (variable dependent). Variabel bebas yaitu: motivasi belajar (X1) dan penguasaan kosakata (X2), sedangkan variablel terikatnya adalah kemampuan menulis naratif bahasa inggris $(\mathrm{Y})$.

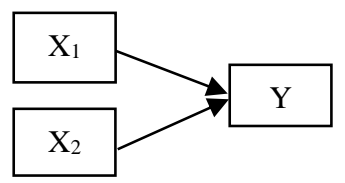

Gambar 1. Model Kontelasi Hubungan antar Variabel Penelitian 
Keterangan: Variabel bebas $(\mathrm{X} 1)=$ motivasi belajar; Variabel bebas $(\mathrm{X} 2)=$ penguasaan kosakata; dan Variabel terikat $(\mathrm{Y})=$ kemampuan menulis naratif bahasa inggris.

Terdapat tiga instrumen dalam penelitian ini yaitu instrumen untuk mengukur hasil motivasi belajar, penguasaan kosakata dan kemampuan menulis naratif Bahasa Inggris. Untuk mempermudah pengumpulan data dalam penelitian, maka dibutuhkan instumen penelitian agar hasil penelitian lebih cermat, lengkap dan sistematis (Arikunto, 2012). Pengumpulan data dalam penelitian ini dilakukan dengan mengumpulkan data instrumen dari hasil kuesioner atau angket motivasi belajar (X1) dan tes tertulis penguasaan kosakata (X2) dan kemampuan menulis naratif bahasa inggris (Y).

Guna memperjelas melihat sumber data penelitian dan teknik pengumbulan data lihat pada Tabel 1 .

Tabel 1. Variabel, Sumber Data dan Teknik Pengumpulan

\begin{tabular}{lcc}
\hline \multicolumn{1}{c}{ Variabel } & Sumber Data & Teknik Pengumpulan \\
\hline Motivasi Belajar & Nilai Siswa & Angket/ kuesioner \\
Penguasaan Kosakata & Nilai Siswa & Tes tertulis \\
Kemampuan Menulis Naratif Bahasa Inggris & Nilai Siswa & Tes tertulis \\
\hline
\end{tabular}

Adapun teknik pengumpulan data tersebut dilakukan dengan langkah-langkah sebagai berikut: (1) melakukan pengujian instrumen motivasi belajar berupa angket atau kuesioner yang berjumlah 30 pertanyaan, (2) melakukan pengujian instrument penguasaan kosakata berbentuk tes tertulis yang meliputi tiga bagian yaitu; synonyms matching, antonyms matching dan complete the missing words in the text dengan total jumlah 30 pertanyaan, (3) melakukan pengujian kemampuan menulis naratif bahasa Inggris siswa berbentuk esai. Pada instrumen ini siswa menulis sebuah karangan berbentuk naratif bahasa Inggris berdasarkan gambar-gambar yang telah disediakan, memeriksa hasil tes siswa/responden dan memberi nilai untuk seluruh tes siswa dan selanjutnya nilai-nilai yanng telah diperoleh tersebut dijadikan data tabulasi untuk ketiga variabel penelitian ini.

Penelitian ini menggunakan kuesioner atau angket tertutup yang dimodifikasi dari angket skala sikap (skala Likert) sebagai instrumen untuk mengukur motivasi belajar siswa. Untuk mengukur sikap, pendapat atau sekelompok orang mengenai fenomena sosial dibutuhkan skala likert (Sugiyono, 2012). Dalam penelitian fenomena sosial ini telah ditetapkan secara spesifik oleh peneliti yang selanjutnya disebut sebagai variable penelitian. Variabel motivasi belajar diukur menggunakan item dengan skala 1 sampai dengan 5 untuk jawaban responden. Sedangkan untuk mengukur penguasaan kosakata dan kemampuan menulis naratif bahasa inggris diperoleh dari hasil tes tertulis siswa.

\section{HASIL DAN PEMBAHASAN}

Hasil penelitian meliputi skor angket motivasi belajar siswa (X1), skor tes hasil kemampuan penguasaan kosakata siswa (X2), dan skor tes hasil kemampuan menulis naratif bahasa Inggris siswa (Y). Data kemampuan menulis naratif bahasa Inggris diperoleh dari nilai tes 90 siswa yang menjadi sampel penelitian. Nilai yang diperoleh adalah terendah 63, tertinggi 98 , rata-rata sebesar 81.70, median sebesar 
83.00, modus sebesar 93 dan simpangan baku sebesar 9.350. Berdasarkan perhitungan skor tes hasil kemampuan menulis naratif bahasa Inggris siswa dengan kriteria deskripsi di atas, diperoleh pada Tabel 3.

Tabel 3. Deskripsi Data Kemampuan Menulis Naratif Bahasa Inggris

\begin{tabular}{llr}
\hline$n$ & Valid & 90 \\
& Missing & 0 \\
\hline Mean & & 81.70 \\
Median & & 83.00 \\
Mode & 93 \\
Std. Deviation & & 9.350 \\
Minimum & 63 \\
Maximum & & 98 \\
\hline
\end{tabular}

Bila dilihat dari hasil perhitungan di atas, maka bisa dikatakan bahwa kemampuan menulis naratif bahasa Inggris siswa SMP Swasta di Kota Bogor tergolong tinggi. Hal ini diindikasikan dengan perolehan skor rata-rata sebesar 81.70. Untuk memperjelas data di atas, digambarkan dalam histogram sebagai berikut.

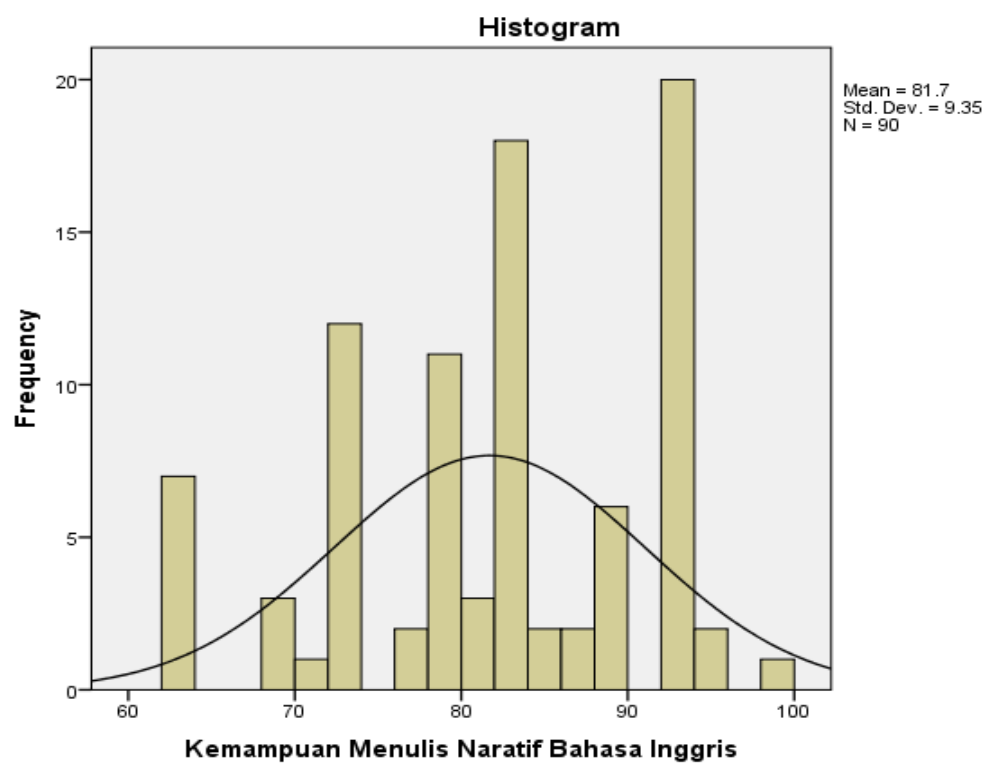

Gambar 2. Histogram Poligon Variabel Kemampuan Menulis Naratif Bahasa Inggris

Dari histogram dan poligon frekuensi di atas dapat disimpulkan bahwa data kemampuan menulis naratif bahasa Inggris siswa SMP Swasta di Kota Bogor memiliki sebaran yang normal.

Data motivasi belajar diperoleh dari skor kuesioner motivasi belajar 90 siswa dihasilkan skor terendah 73, skor tertinggi 111, skor rerata sebesar 94.79, median 93.00, modus sebesar 88, dan simpangan baku sebesar 8.804. Berdasarkan perhitungan skor angket motivasi belajar siswa dengan kriteria deskripsi di atas, diperoleh hasil dalam Tabel 4. 
Tabel 4. Deskripsi Data Penelitian Motivasi Belajar

\begin{tabular}{lcr}
\hline$n$ & Valid & 90 \\
\hline Mean & Missing & 0 \\
Median & & 94.79 \\
Mode & 93.00 \\
Std. Deviation & $88^{\mathrm{a}}$ \\
Minimum & 8.804 \\
Maximum & 73 \\
\hline
\end{tabular}

a. Multiple modes exist. The smallest value is shown

Dari hasil perhitungan di atas, maka bisa dikatakan bahwa motivasi belajar siswa SMP Swasta di Kota Bogor tergolong tinggi. Hal ini diindikasikan dengan perolehan skor rerata sebesar 94.79. Untuk memperjelas data di atas, digambarkan dalam histogram sebagai berikut.

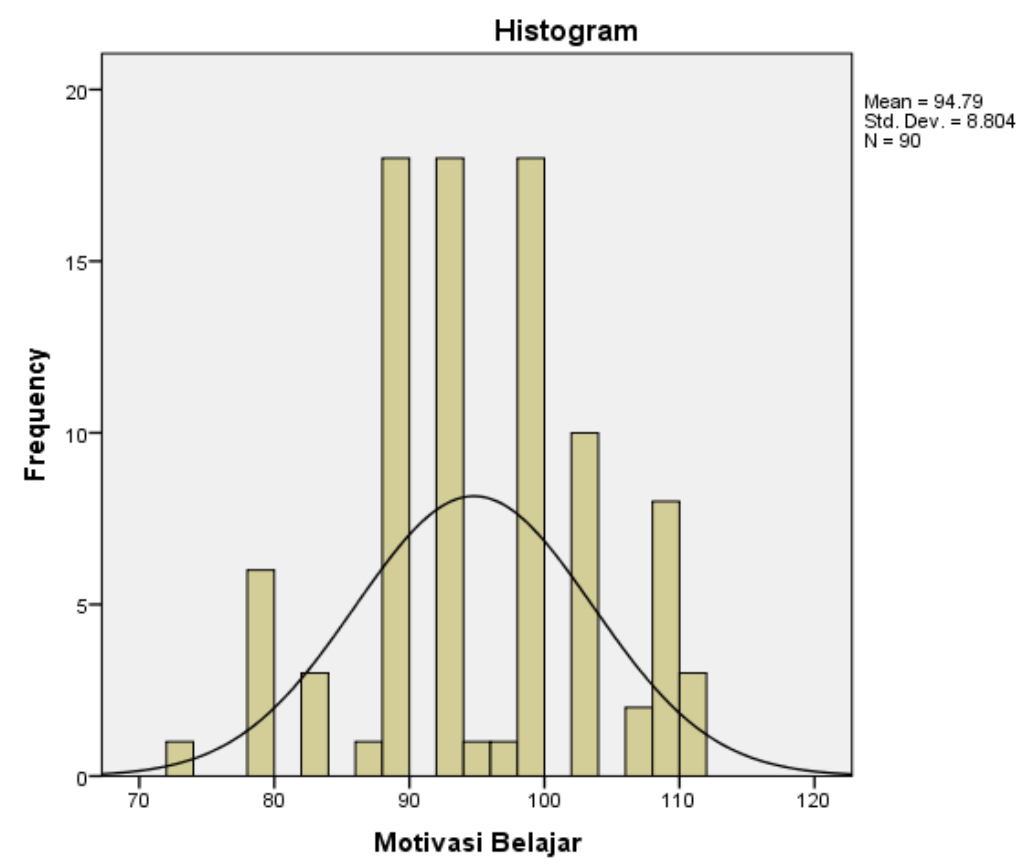

Gambar 3. Histogram Poligon Variabel Motivasi Belajar

Dari histogram dan poligon frekuensi di atas dapat disimpulkan bahwa motivasi belajar siswa SMP Swasta di Kota Bogor memiliki sebaran yang normal.

Data penguasaan kosakata diperoleh dari nilai tes yang dijawab oleh 90 siswa sebagai responden dihasilkan nilai terendah 65 , nilai tertinggi 95 , nilai rerata sebesar 80.50, median sebesar 80.00, modus sebesar 80 dan simpangan baku sebesar 8.212. Berdasarkan perhitungan skor tes penguasaan kosakata siswa dengan kriteria deskripsi di atas, diperoleh hasil dalam Tabel 5. 
125| Solihat, Pengaruh Motivasi Belajar dan Penguasaan Kosakata ...

Tabel 5. Deskripsi Data Penelitian Motivasi Belajar

\begin{tabular}{llr}
\hline$n$ & Valid & 90 \\
Mean & Missing & 0 \\
Median & & 80.50 \\
Mode & & 80.00 \\
Std. Deviation & & 80 \\
Minimum & 8.212 \\
Maximum & & 65 \\
\hline
\end{tabular}

Dari hasil perhitungan di atas, maka bisa dikatakan bahwa penguasaan kosakata siswa SMP Swasta di Kota Bogor tergolong tinggi. Hal ini diindikasikan dengan perolehan nilai rerata skor penguasaan kosakata 80.50. Untuk memperjelas data di atas, digambarkan dalam histogram sebagai berikut.

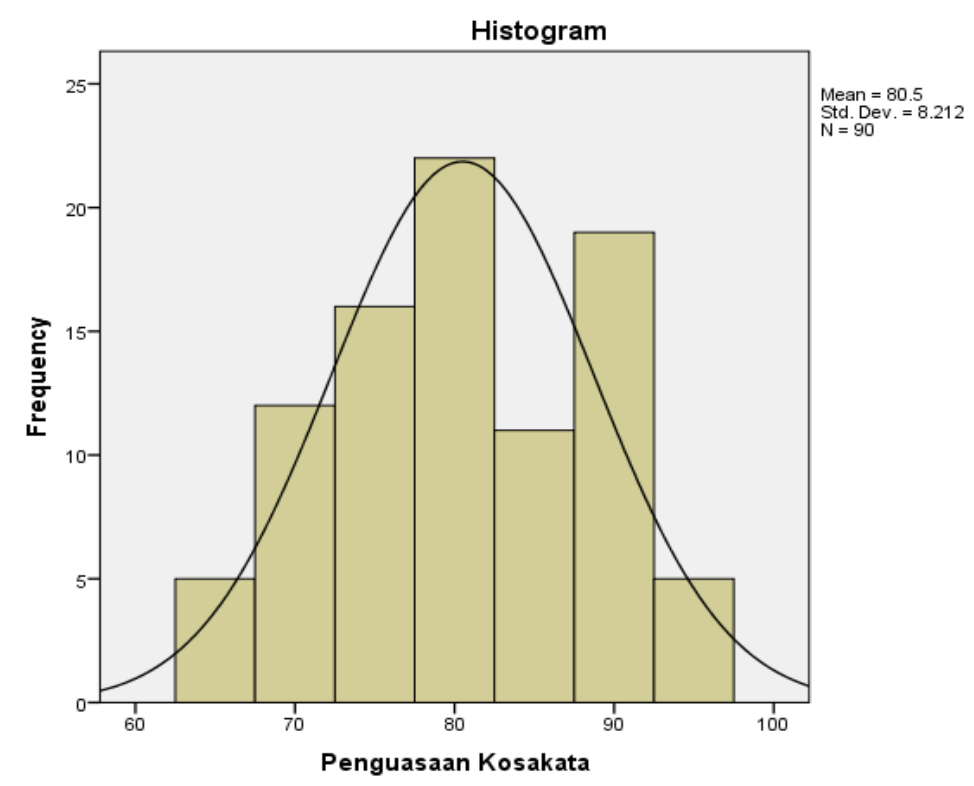

Gambar 4. Histogram Poligon Variabel Penguasaan Kosakata

Dari histogram dan polygon frekuensi di atas dapat disimpulkan bahwa penguasaan kosakata siswa SMP Swasta di Kota Bogor memiliki sebaran yang normal.

Persyaratan regresi yang baik adalah jika data penelitian mengikuti distribusi normal.

Dari Tabel 6 di atas menunjukkan bahwa uji hipotesis yang menyatakan distribusi data pada analisis regresi ini mengikuti distribusi normal. Hal ini ditunjukkan dengan semua nilai Asymp. Sig.>0.05. Hal ini berarti semua data berdistribusi normal. 
Tabel 6. One-Sample Kolmogorov-Smirnov Test

\begin{tabular}{llccc}
\hline & & $\begin{array}{c}\text { Kemampuan Menulis } \\
\text { Naratif Bahasa Inggris }\end{array}$ & $\begin{array}{c}\text { Motivasi } \\
\text { Belajar }\end{array}$ & $\begin{array}{c}\text { Penguasaan } \\
\text { Kosakata }\end{array}$ \\
\hline$n$ & Mean & 90 & 90 & 90 \\
Normal & Std. & 91.70 & 94.79 & 80.56 \\
Parameters ${ }^{\mathrm{a}, \mathrm{b}}$ & Deviation & 9.350 & 8.804 & 8.226 \\
& Absolute & .142 & .103 & .141 \\
Most Extreme & Positive & .080 & .103 & .127 \\
Differences & Negative & -.142 & -.098 & -.141 \\
Kolmogorov-Smirnov Z & 1.348 & .975 & 1.340 \\
Asymp. Sig. (2-tailed) & .053 & .298 & .055 \\
\hline
\end{tabular}

a. Test distribution is Normal; b. Calculated from data.

Tujuan dari uji multikolinieritas yaitu untuk menguji terdapat atau tidaknya korelasi yang sempurna antar variable bebas (independent). Menurut Ghozali (2013) bahwa model regresi dikatakan baik apabila tidak terjadi korelasi diantara variable bebas (independent). Dalam mendeteksi adanya multikolinieritas yaitu dengan melihat tolerance atau Varian Inflation Factor (VIF). Apabila tolerance kurang dari 0.1 atau nilai VIF lebih dari10 maka terjadi multikolinearitas.

Tabel 7. Uji Multikolinearitas

\begin{tabular}{llrc}
\hline \multicolumn{4}{c}{ Coefficients } \\
\hline \multicolumn{3}{c}{ Model } & Collinearity Statistics \\
& Tolerance & VIF \\
\hline (Constant) & & \\
1 Motivasi Belajar & .934 & 1.071 \\
Penguasaan Kosakata & .934 & 1.071 \\
\hline
\end{tabular}

Hasil uji multikolininearitas pada tabel di atas diketahui bahwa hasil Tolerance $0.934>0.1$ atau $\mathrm{VIF}=1.071<10$. Sehingga dapat dinyatakan bahwa tidak ada multikolinearitas antara motivasi belajar dengan penguasaan kosakata pada analisis regresi ganda ini.

Uji heteroskedastisitas yaitu apabila kesalahan atau residual yang diamati tidak memiliki varian yang konstan. Kondisi heteroskedastisitas sering terjadi pada data cross section, atau data yang diambil dari beberapa responden pada suatu waktu tertentu. Pada gambar dibawah ini menunjukkan tidak ada perubahan e sepanjang Y topi, maka dinyatakan tidak ada heteroskedastisitas pada galat (error/residual).

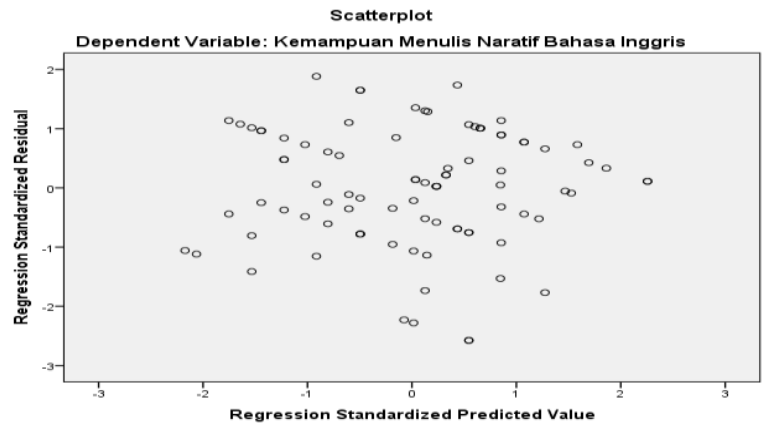

Gambar 5. Scatterplot Uji Heteroskedastisitas 
Dari gambar di atas menunjukkan titik terbentuk pola yang jelas dan titik tersebar secara acak baik di atas maupun di bawah angka 0 pada sumbu Y. Hal ini dapat dikatakan bahwa tidak terjadi heteroskedastisitas pada model regresi tersebut sehingga dapat digunakan untuk memprediksi variable kemampuan menulis naratif bahasa Inggris berdasarkan motivasi belajar dan penguasaan kosakata. Persyaratan regresi yang baik jika data penelitian mengikuti distribusi normal.

Tabel 8. Uji Normalitas Galat

\begin{tabular}{llr}
\hline \multicolumn{2}{c}{ One-Sample Kolmogorov-Smirnov Test } \\
\hline$n$ & & Unstandardized Residual \\
\hline \multirow{2}{*}{ Normal Parameters ${ }^{\mathrm{a}, \mathrm{b}}$} & Mean & 90 \\
& Std. Deviation & $0 \mathrm{E}-7$ \\
& Absolute & 8.13933117 \\
Most Extreme Differences & Positive & .070 \\
& Negative & .047 \\
Kolmogorov-Smirnov Z & & -.070 \\
Asymp. Sig. (2-tailed) & & .662 \\
\hline
\end{tabular}

a. Test distribution is Normal; b. Calculated from data.

Dari Tabel 8 menunjukkan bahwa uji hipotesis yang menyatakan distribusi residual pada analisis regresi ini mengikuti distribusi normal. Hal ini ditunjukkan dengan nilai $Z=0.662$ dan Sig. $=0.774>0.05$. Hal ini berarti asumsi atau persyaratan analisis regresi terpenuhi.

\section{Pengaruh Motivasi Belajar (X1) terhadap Kemampuan Menulis Naratif Bahasa Inggris (Y)}

Hasil uji linearitas regresi antara motivasi belajar dengan kemampuan menulis naratif bahasa Inggris, perhitungan SPSS 20.0 sebagai berikut.

Tabel 9. Hasil Pengujian Linearitas Regresi Variabel $\mathrm{Y}$ atas $\mathrm{X}_{1}$

\begin{tabular}{|c|c|c|c|c|c|c|c|}
\hline & & & $\begin{array}{l}\text { Sum of } \\
\text { Squares }\end{array}$ & $d f$ & $\begin{array}{l}\text { Mean } \\
\text { Square }\end{array}$ & $F$ & Sig. \\
\hline \multirow{3}{*}{$\begin{array}{l}\text { Kemampuan } \\
\text { Menulis } \\
\text { Naratif } \\
\text { Bahasa } \\
\text { Inggris }\end{array}$} & \multirow{3}{*}{$\begin{array}{l}\text { Between } \\
\text { Groups }\end{array}$} & (Combined) & 2227.233 & 14 & 159.088 & 2.148 & .018 \\
\hline & & Linearity & 1426.680 & 1 & 1426.680 & 19.267 & .000 \\
\hline & & $\begin{array}{l}\text { Deviation from } \\
\text { Linearity }\end{array}$ & 800.553 & 13 & 61.581 & .832 & .626 \\
\hline $\begin{array}{l}\text { Motivasi } \\
\text { Belajar }\end{array}$ & $\begin{array}{l}\text { Within G1 } \\
\text { Total }\end{array}$ & & $\begin{array}{l}5553.667 \\
7780.900 \\
\end{array}$ & $\begin{array}{l}75 \\
89 \\
\end{array}$ & 74.049 & & \\
\hline
\end{tabular}

Berdasarkan hasil perhiungan di atas diperoleh hasil perhitungan Deviation from Linearity dengan $F_{0}=0.832$ dan Sig. $=0.626>0.05$. Hal ini memiliki pengertian bahwa variabel motivasi belajar dengan kemampuan menulis naratif bahasa Inggris siswa mempunyai mempunyai hubungan yang linear. 
Pengaruh Penguasaan Kosakata (X2) terhadap Kemampuan Menulis Naratif Bahasa Inggris (Y)

Hasil uji linearitas regresi antara penguasaan kosakata dengan kemampuan menulis naratif bahasa Inggris, perhitungan SPSS 20.0 sebagai berikut:

Tabel 10. Hasil Pengujian Linearitas Regresi Variabel $\mathrm{Y}$ atas $\mathrm{X}_{2}$

\begin{tabular}{|c|c|c|c|c|c|c|c|}
\hline & & & $\begin{array}{l}\text { Sum of } \\
\text { Squares }\end{array}$ & $d f$ & $\begin{array}{l}\text { Mean } \\
\text { Square }\end{array}$ & $F$ & Sig. \\
\hline \multirow{6}{*}{$\begin{array}{l}\text { Kemampuan Menulis } \\
\text { Naratif Bahasa } \\
\text { Inggris* Penguasaan } \\
\text { Kosakata }\end{array}$} & \multirow{4}{*}{$\begin{array}{l}\text { Between } \\
\text { Groups }\end{array}$} & (Combined) & 1329.709 & 6 & 221.618 & 2.851 & .014 \\
\hline & & Linearity & 924.841 & 1 & 924.841 & 11.899 & .001 \\
\hline & & Deviation & & & & \multirow{4}{*}{1.042} & \\
\hline & & $\begin{array}{l}\text { from } \\
\text { Linearity }\end{array}$ & 404.868 & 5 & 80.974 & & .399 \\
\hline & \multicolumn{2}{|c|}{ Within Groups } & 6451.191 & 83 & 77.725 & & \\
\hline & \multicolumn{2}{|l|}{ Total } & 7780.900 & 89 & & & \\
\hline
\end{tabular}

Berdasarkan hasil perhitungan di atas diperoleh hasil Deviation from Linearity dengan $F_{0}=1.360$ dan Sig. $=0.243>0.05$. Hal ini memiliki pengertian bahwa variabel penguasaan kosakata dengan kemampuan menulis naratif bahasa Inggris siswa mempunyai mempunyai hubungan yang linear.

\section{Pengaruh Motivasi Belajar (X1) dan Penguasaan Kosakata (X2) terhadap Kemampuan Menulis Naratif Bahasa Inggris ( $Y$ )}

Pengujian hipotesis dengan menggunakan analisis regresi dan korelasi ganda dalam hal ini pengaruh motivasi belajar (X1) dan penguasaan kosakata (X2) terhadap kemampuan menulis naratif bahasa Inggris (Y). Pengujian hipotesis dilakukan dengan penggunakan teknik analisis regresi dan korelasi ganda. Berdasarkan hasil perhitungan SPSS 20.0 diperoleh hasil sebagai berikut: Hipotesis pertama; terdapat pengaruh motivasi belajar dan penguasaan kosakata secara bersama-sama terhadap kemampuan menulis naratif Bahasa Inggris. Untuk menguji hipotesis ini digunakan korelasi dan regresi ganda, dengan hasil perhitungan sebagai berikut.

Tabel 11. Hasil Perhitungan Pengujian

\begin{tabular}{lcccc}
\multicolumn{4}{c}{ Koefisien Korelasi Ganda Variabel $\mathrm{X}_{1}$ dan $\mathrm{X}_{2}$ terhadap $\mathrm{Y}$} \\
\hline \multicolumn{5}{c}{ Model Summary } \\
\hline Model & $R$ & $R$ Square & Adjusted $R$ Square & Std. Error of the Estimate \\
\hline 1 & $.492^{\mathrm{a}}$ & .242 & .225 & 8.232 \\
\hline & & Predictors: (Constant), Penguasaan Kosakata, Motivasi Belajar
\end{tabular}

Pada Tabel 11 diperoleh hasil koefesien korelasi sebesar 0.492 hal ini menunjukkan bahwa terdapat pengaruh yang signifikan antara motivasi belajar dna penguasaan kosakata terhadap kemampuan menulis naratif bahasa Inggris. Koefisien determinasi yang dihasilkan sebesar 0.225 atau $24.2 \%$. Hal ini dapat diartikan bahwa kemampuan menulis naratif bahsa Inggris dipengaruhi oleh motivasi belajar dan penguasaan kosakata sebesar $24.2 \%$, sedangkan 75.8 dipengaruh oleh faktor lain. Dengan demikian dapat disimpulkan hipotesis $(\mathrm{Ha})$ diterima, yaitu terdapat hubungan signifikan antara motivasi belajar dan 
penguasaan kosakata siswa secara bersama-sama terhadap kemampuan menulis naratif bahasa Inggris pada siswa VII SMP Swasta di Kota Bogor.

Tabel 12. Hasil Perhitungan Pengujian Signifikansi

Koefisien Regresi Variabel $\mathrm{X}_{1}$ dan $\mathrm{X}_{2}$ terhadap Y

\begin{tabular}{lrrrrr}
\hline Model & Sum of Squares & $d f$ & Mean Square & $F$ & Sig. \\
\hline Regression & 1884.765 & 2 & 942.382 & 13.905 & $.000^{\mathrm{b}}$ \\
1 Residual & 5896.135 & 87 & 67.772 & & \\
$\quad$ Total & 7780.900 & 89 & & & \\
\hline
\end{tabular}

a. Dependent Variable: Kemampuan Menulis Naratif Bahasa Inggris

b. Predictors: (Constant), Penguasaan Kosakata, Motivasi Belajar

Pada Tabel 12 dapat dilihat bahwa nilai signifikansi pada deviation from linearity sebesar 0.000 , karena nilai tersebut kurang dari 0.05 maka dapat disimpulkan bahwa persamaan regresi yang dihasilkan antara varibel motivasi belajar dan penguasaan kosakata terhadap kemampuan menulis naratif Bahasa Inggris berbentuk linear atau dapat dinyatakan bahwa terdapat pengaruh yang signifikan motivasi belajar dan penguasaan kosakata secara bersama-sama terhadap kemampuan menulis naratif bahasa Inggris. Hal ini dibuktikan dengan perolehan nilai Sig. $0.000<0.05$ dan $F_{\mathrm{h}}=13.905$.

Tabel 13. Hasil Perhitungan Persamaan Regresi Ganda Variabel $\mathrm{X}_{1}$ dan $\mathrm{X}_{2}$ terhadap $\mathrm{Y}$

\begin{tabular}{|c|c|c|c|c|c|c|}
\hline & \multirow[t]{2}{*}{ Model } & \multicolumn{2}{|c|}{$\begin{array}{l}\text { Unstandardized } \\
\text { Coefficients }\end{array}$} & \multirow{2}{*}{$\begin{array}{c}\text { Standardized } \\
\text { Coefficients } \\
\text { Beta }\end{array}$} & \multirow[t]{2}{*}{$t$} & \multirow[t]{2}{*}{ Sig. } \\
\hline & & $B$ & $S E$ & & & \\
\hline \multirow{3}{*}{1} & (Constant) & 22.114 & 11.367 & & 1.945 & .055 \\
\hline & Motivasi Belajar & .386 & .103 & .364 & 3.764 & .000 \\
\hline & Penguasaan Kosakata & .285 & .110 & .251 & 2.600 & .011 \\
\hline
\end{tabular}

a. Dependent Variable: Kemampuan Menulis Naratif Bahasa Inggris

Dari hasil perhitungan dan analisis data tersebut diatas diperoleh persamaan regresi $\hat{Y}=22.114+0.386 \mathrm{X}_{1}+0.285 X_{2}$. Hal ini memiliki pengertian bahwa kenaikan satu skor variabel motivasi belajar dan penguasaan kosakata memberikan kontribusi sebesar 0.386 oleh $\mathrm{X}_{1}$ dan 0.285 oleh $\mathrm{X}_{2}$ terhadap variabel kemampuan menulis naratif bahasa Inggris. Dari Tabel 11 juga dapat menjelaskan bahwa secara bersama-sama variabel motivasi belajar dan penguasaan kosakata memberikan kontribusi sebesar $24.2 \%$ terhadap variabel kemampuan menulis naratif bahasa Inggris.

Pada Tabel 13 dapat dinyatakan bahwa terdapat pengaruh yang signifikan motivasi belajar terhadap kemampuan menulis naratif bahasa Inggris. Hal ini dibuktikan dengan perolehan nilai Sig. $=0.000<0.05$ dan $t_{\mathrm{h}}=3.764$. Adapun kontribusi variabel motivasi belajar terhadap kemampuan menulis naratif bahasa Inggris dapat dinyatakan dengan rumus: $\mathrm{KD}=$ Nilai $\beta_{x 1 y} \times$ Nilai Korelasi Pasialnya

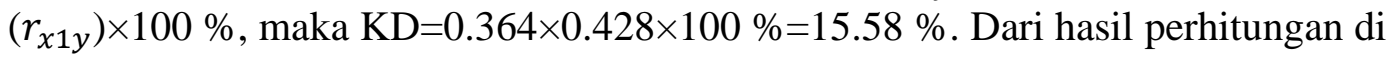
atas dapat dinyatakan bahwa kontribusi motivasi belajar dalam meningkatkan kemampuan menulis naratif bahasa Inggris sebesar $15.58 \%$. Selain itu, pada tabel 13. dinyatakan bahwa terdapat pengaruh yang signifikan penguasaan kosakata terhadap kemampuan menulis naratif bahasa Inggris. Hal ini dibuktikan dengan 
perolehan nilai Sig. $=0,011<0,05$ dan $t_{\mathrm{h}}=2.600$. Adapun kontribusi variabel penguasaan kosakata terhadap kemampuan menulis naratif bahasa Inggris dapat dinyatakan dengan rumus: KD=Nilai $\beta_{x 2 y} \times$ Nilai Korelasi Pasialnya $\left(r_{x 2 y}\right) \times 100 \%$, maka $\mathrm{KD}=0.251 \times 0.345 \times 100 \%=8.66 \%$. Dari hasil perhitungan di atas dapat dinyatakan bahwa kontribusi penguasaan kosakata dalam meningkatkan kemampuan menulis naratif bahasa Inggris sebesar $8.66 \%$.

Implikasi dalam penelitian ini adalah motivasi belajar dan penguasaan kosakata secara bersama-sama telah memberikan pengaruh positif terhadap peningkatan kemampuan menulis naratif bahasa Inggris siswa SMP Swasta di Kota Bogor. Hal ini mengandung arti bahwa motivasi belajar dan penguasaan kosakata telah memberikan pengaruh yang signifikan terhadap peningkatan kemampuan menulis naratif bahasa Inggris siswa SMP Swasta di Kota Bogor. Hal ini sejalan dengan penelitian yang dilakukan oleh Sugiyo (2016) bahwa terdapat pengaruh yang signifikan antara motivasi belajar dan penguasaan kosakata terhadap kemampuan menulis naratif. Dengan motivasi belajar yang tinggi dan penguasaan kosakata yang baik maka siswa mendaptkan hasil belajar yang baik, sehingga dapat dismpulkan bahwa terdapat pengaruh positif motivasi belajar dan penguasaan kosakata secara bersama-sama terhadap kemampuan menulis naratif bahasa Inggris.

Hasil penelitian ini sejalan dengan hasil penelitian yang dilakukan sebelumnya oleh Nurhuda (2015) dan Setyawan, Andayani \& Wardhani (2015) yang menemukan bahwa motivasi belajar dan penguasaan kosakata dapat meningkatkan kemampuan menulis naratif bahasa Inggris siswa.

\section{KESIMPULAN}

Terdapat hubungan signifikan antara motivasi belajar dan penguasaan kosakata secara Bersama-sama terhadap kemampuan menulis naratif bahasa Inggris pada siswa kelas VII SMP Swasta di Kota Bogor. Dengan demikian makna dari hasil analisis regresi dan korelasi tersebut menunjukkan bahwa semakin tinggi motivasi belajar dan penguasaan kosakata yang dimiliki siswa secara Bersama-sama maka akan semakin baik pula hasil karangannya atau naratif bahasa Inggris.

Terdapat hubungan signifikan antara motivasi belajar terhadap kemampuan menulis naratif bahasa Inggris pada siswa kelas VII SMP Swasta di Kota Bogor. Dengan demikian makna dari hasil analisis regresi dan korelasi tersebut menunjukkan bahwa semakin tinggi motivasi belajar yang dimiliki siswa semakin mudah dalam menulis naratif bahasa Inggris.

Terdapat hubungan yang signifikan antara motivasi belajar dan penguasaan kosakata terhadap kemampuan menulis naratif bahasa Inggris pada siswa kelas VII SMP Swasta di Kota Bogor. Dengan demikian makna dari hasil analisis regresi dan korelasi tersebut menunjukkan bahwa semakin banyak kosakata yang dimiliki siswa akan semakin mudah pula siswa menuangkan ide, memilih kosakata yang tepat, dan menyampaikan maksud yang dapat ditangkap oleh pembaca dalam menulis naratif bahasa Ingris.

\section{REFERENSI}

Arikunto, S. (2012). Prosedur Penelitian: Suatu Pendekatan Praktik. Jakarta: Rineka Cipta. 
Crystal, D. (2003). English as a Global Language. Cambridge, UK: Cambridge University Press.

Ghozali, I. (2013). Aplikasi Analisis Multivariate dengan Program IBM SPSS 21. Semarang: Badan Penerbit UNDIP.

Kerlinger, F. N. (2003). Asas-asas Penelitian Behavioral. Terjemahan Landung R. Yogyakarta: Gadjah Mada University Press.

Nurhuda, Z. (2015). Dosen Tetap pada Program Studi Sastra Indonesia Fakultas Sastra Universitas Pamulang 70. Sasindo Unpam, 3(3), 70-108.

Nurjamal. N. (2010). Penuntun Perkuliahan Bahasa Indonesia. Bandung: Alfa Beta Sanjaya, W. (2008). Kurikulum dan Pembelajaran. Jakarta: Kencana.

Setyawan, A., Andayani, A., \& Wardhani, N. (2015). Hubungan Antara Penguasaan Kosakata Dan Motivasi Belajar Dengan Keterampilan Menulis Teks Narasi Pada Siswa Kelas XI SMK Negeri 1 Sawit Boyolali Tahun Ajaran 2014/2015. Jurnal Penelitian Bahasa, Sastra Indonesia, Dan Pengajarannya, 3(2), 53845. Siregar, E., \& Nara, H. (2014). Teori Belajar dan Pembelajaran. Bogor: Ghalia Indonesia.

Sugiyono. (2012). Metode Penelitian Pendiidkan, Pendekatan Kuantitatif, Kualitatif, dan $R \& D$. Bandung: Angkasa.

Tarigan, H. G. (2015). Pengajaran Kosakata. Bandung: Angkasa

Uno, H. B. (2011). Teori Motivasi dan Pengukurannya. Jakarta: Bumi Aksara. 